\title{
Rhizobium alamii sp. nov., an exopolysaccharide- producing species isolated from legume and non-legume rhizospheres
}

Correspondence

Odile Berge odile.berge@cea.fr
Odile Berge, ${ }^{1,2,3}$ Asma Lodhi, ${ }^{1,2,3}$ † Géraldine Brandelet, ${ }^{1,2,3}$ Catherine Santaella, 1,2,3 Marie-Anne Roncato, 1,2,3 Richard Christen, ${ }^{4,5}$ Thierry Heulin ${ }^{1,2,3}$ and Wafa Achouak ${ }^{1,2,3}$

\author{
${ }^{1}$ CEA, DSV, IBEB, SBVME, Laboratoire d'Écologie Microbienne de la Rhizosphère et \\ d'Environnements Extrêmes (LEMiRE), F-13108 Saint-Paul-lez-Durance, France \\ ${ }^{2}$ CNRS, UMR 6191, F-13108 Saint-Paul-lez-Durance, France \\ ${ }^{3}$ Aix-Marseille Université, F-13108 Saint-Paul-lez-Durance, France \\ ${ }^{4}$ CNRS, UMR 6543, Laboratoire de Biologie Virtuelle, Parc Valrose, F-06108 Nice, France \\ ${ }^{5}$ Université de Nice, Parc Valrose, Centre de Biochimie, F-06108 Nice, France
}

Rhizobium species were originally known for their symbiotic association with members of the Fabaceae (Leguminosae), and their nomenclature was shaped by the specificity of their symbiotic plant range. Since the recognition that the Sym plasmid responsible for nodulation and specificity can be lost or transferred between strains related to Rhizobium, the nomenclature has been revised, based on phylogenetic and phenotypic data. All Agrobacterium and Allorhizobium species were included in the genus Rhizobium (Young et al., 2001), and the genus consists of 24 species at present. These taxonomic revisions emphasize that the non-symbiotic lifestyle of rhizobia is also of ecological importance (Denison \& Kiers, 2004). Free-living Rhizobium strains have frequently been isolated from soil (Soberon-Chavez \& Najera, 1988; Laguerre et al.,

†Present address: Nuclear Institute for Agriculture and Biology, PO Box 128, Jhang Road, Faisalabad 38000, Pakistan.

Abbreviation: EPS, exopolysaccharide.

The GenBank/EMBL/DDBJ accession number for the 16S rRNA gene sequence of strain GBV016 ${ }^{\top}$ is $\mathrm{AM} 931436$.

A photograph of colonies of one of the novel strains showing EPS production and details of DNA-DNA hybridization results are available as supplementary material with the online version of this paper.
1993; Quigley et al., 1997), rhizospheres and plant roots (Segovia et al., 1991; Sullivan et al., 1996; Yanni et al., 1997; Rosenblueth \& Martinez-Romero, 2004) and, recently, three Rhizobium species have been described on the basis of non-symbiotic strains isolated from bioreactors (Quan et al., 2005; Hunter et al., 2007) and sawdust of Populus alba (Garcia-Fraile et al., 2007). Rhizobium species are likely to be involved in a broad range of functions in diverse ecosystems.

Rhizobium sp. YAS34 was selected from the indigenous sunflower taproot microflora for its ability to produce large amounts of gel-forming exopolysaccharides (EPS) (Alami et al., 1998) that play an active role in plant development in a non-symbiotic context (Alami et al., 2000), whereas EPS production by rhizobium populations is usually known to be crucial for establishment of successful symbiosis with legumes. Alami et al. (2000) classified strain YAS34 within the genus Rhizobium but it was unlike any of the previously described species, on the basis of its complete 16S rRNA gene sequence. Within the framework of a study of bacterial EPS in the rhizosphere of Arabidopsis thaliana, a group of nine isolates was assigned to an undescribed Rhizobium species closely related to YAS34. In the present 
study, the strains were investigated in detail and the results suggest that these strains belong to a novel Rhizobium species.

EPS-producing strains were isolated from the indigenous bacterial populations of $A$. thaliana roots and rhizosphere soil by growing plants for 1 month in soil as described by Achouak et al. (2004). Pots were kept at $30{ }^{\circ} \mathrm{C}$ for seed germination and then shifted to a Phytotron under controlled conditions ( $8 \mathrm{~h}$ light, $16 \mathrm{~h}$ dark; $22 / 18{ }^{\circ} \mathrm{C}$ day/ night; relative humidity $50 \%$ ). Soil was sampled in a eutric cambisol soil from Versailles, France (Derrien et al., 2006). At harvest, following the methods of Amellal et al. (1998), macerated, washed roots and samples of soil adhering to roots were diluted and plated on RCV medium containing $20 \mathrm{~g}$ glucose $1^{-1}$ (RCV-Gluc). The composition of RCV medium $\left(\mathrm{l}^{-1}\right)$ was as follows: $\mathrm{MgSO}_{4} \cdot 7 \mathrm{H}_{2} \mathrm{O}, 100 \mathrm{mg}$; $\mathrm{CaCl}_{2} \cdot 2 \mathrm{H}_{2} \mathrm{O}, 100 \mathrm{mg} ; \mathrm{FeSO}_{4} \cdot 7 \mathrm{H}_{2} \mathrm{O}, 22 \mathrm{mg} ;$ EDTA, $20 \mathrm{mg} ; \mathrm{ZnSO}_{4} .7 \mathrm{H}_{2} \mathrm{O}, 0.43 \mathrm{mg} ; \mathrm{MnSO}_{4} . \mathrm{H}_{2} \mathrm{O}, 1.30 \mathrm{mg}$; $\mathrm{Na}_{2} \mathrm{MoO}_{4} \cdot 2 \mathrm{H}_{2} \mathrm{O}, \quad 0.75 \mathrm{mg} ; \quad \mathrm{H}_{3} \mathrm{BO}_{3}, \quad 2.80 \mathrm{mg}$; $\mathrm{CuSO}_{4} \cdot 5 \mathrm{H}_{2} \mathrm{O}, 26 \mu \mathrm{g} ; \mathrm{CoSO}_{4} .7 \mathrm{H}_{2} \mathrm{O}, 70 \mu \mathrm{g} ; \mathrm{K}_{2} \mathrm{HPO}_{4}$, $5.2 \mathrm{mM} ; \mathrm{KH}_{2} \mathrm{PO}_{4}, 4.4 \mathrm{mM}$; yeast extract, $0.1 \mathrm{mg} ; \mathrm{pH} 6.8$. After 4-10 days at $30{ }^{\circ} \mathrm{C}$, mucous strains constituted 20 $30 \%$ of the cultivable bacteria from the root environment. This represents a fivefold greater proportion than in bulk soil sampled in control pots without plants, showing the effect of the rhizosphere on these mucous bacterial populations. An example of EPS production by these strains on RCV-Gluc medium is shown in Supplementary Fig. S1 (available in IJSEM Online). Eighty-four representative isolates from roots and root-adhering soil were purified on tenfold-diluted trypticase soy agar $(0.1 \times$ TSA $)$.
Their role in the function of the A. thaliana rhizosphere and their EPS structures are under investigation.

Partial sequences of the $16 \mathrm{~S}$ rRNA gene $(380 \mathrm{bp}$ ) were obtained with primers Fd1 and S6 for most of the strains according to Berge et al. (2002) to classify them rapidly by using the BLASTN program (Altschul et al., 1997) and sequences available in GenBank. The majority of these culturable mucous strains $(>70 \%)$ were affiliated to the genera Rhizobium or Sinorhizobium (Ensifer), showing the prevalence of this group in the rhizosphere of A. thaliana. Partial $16 \mathrm{~S}$ rRNA gene sequences showed that 37 isolates had $99.5 \%$ identity with Rhizobium sp. YAS34 and USDA 1920, the single isolate representing one of the three genomic species that form nitrogen-fixing symbioses with Medicago ruthenica (van Berkum et al., 1998), suggesting that they belong to the same species. A representative subset of this collection, isolated from three independent experiments and five $A$. thaliana plants, was investigated in this study. Their origin and the reference organisms used in this work are listed in Table 1.

The diversity of strains was assessed by ERIC-PCR and REP-PCR analyses as described by Frey et al. (1997). Strains isolated from A. thaliana are characterized by different REP- and ERIC-PCR profiles (Table 1), demonstrating that these strains originating from the same soil are not clones. Together with strains YAS34 and USDA 1920, respectively isolated from sunflower and M. ruthenica, they represent a bacterial strain collection from different sites and hosts as recommended for the description of novel Rhizobium species (Lindström \& Martinez-Romero, 2007).

Table 1. Origin and characteristic of strains used in this study

CNCM, Collection Nationale de Culture Microbienne (Institut Pasteur, France); USDA, US Department of Agriculture; P, Patent strains of CEACNRS-ARD. ND, Not determined.

\begin{tabular}{|c|c|c|c|c|}
\hline \multirow[t]{2}{*}{ Strain } & \multirow[t]{2}{*}{ Origin of isolation } & \multicolumn{2}{|c|}{ PCR profile } & \multirow[t]{2}{*}{ Reference } \\
\hline & & REP-PCR & ERIC-PCR & \\
\hline \multicolumn{5}{|l|}{ Rhizobium alamii sp. nov. } \\
\hline GBV016 ${ }^{\mathrm{T}}$ & Rhizosphere, A. thaliana plant 1 & $\mathrm{a}$ & $\mathrm{A} 1^{\star}$ & This study \\
\hline GBV022 & Rhizosphere, A. thaliana plant 2 & $\mathrm{~b}$ & $\mathrm{~A} 2$ & This study \\
\hline GBV023 & Rhizosphere, $A$. thaliana plant 2 & c & B1 & This study \\
\hline GBV024 & Roots, A. thaliana plant 3 & $\mathrm{~d}$ & $\mathrm{C}$ & This study \\
\hline GBV037 & Roots, A. thaliana plant 3 & e & $\mathrm{D}$ & This study \\
\hline GBV081 & Roots, A. thaliana plant 3 & $\mathrm{f}$ & B2 & This study \\
\hline GBV044 & Roots, A. thaliana plant 4 & $\mathrm{~h}$ & $\mathrm{E}$ & This study \\
\hline ALV118 & Roots, A. thaliana plant 5 & $\mathrm{i}$ & B3 & This study \\
\hline 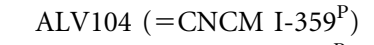 & Roots, A. thaliana plant 5 & j & $\mathrm{F}$ & Lodhi-Hassan et al. (2006) \\
\hline YAS34 $\left(=\right.$ CNCM I-1809 $\left.{ }^{\mathrm{P}}\right)$ & Sunflower roots & $\mathrm{k}$ & G & Alami et al. (1998) \\
\hline USDA 1920 & Medicago ruthenica & 1 & $\mathrm{H}$ & van Berkum et al. (1998) \\
\hline R. sullae USDA $4950^{\mathrm{T}}$ & Hedysarum coronarium & ND & $\mathrm{ND}$ & Squartini et al. (2002) \\
\hline R. mongolense USDA $1844^{\mathrm{T}}$ & Medicago ruthenica & $\mathrm{n}$ & $\mathrm{J}$ & van Berkum et al. (1998) \\
\hline R. gallicum $\mathrm{R} 602 \mathrm{sp}^{\mathrm{T}}$ & Phaseolus vulgaris & ND & ND & Amarger et al. (1997) \\
\hline
\end{tabular}

${ }^{\star}$ Profiles with the same letter shared the majority of bands. 
The nearly complete 16S rRNA gene sequence of strain GBV016 ${ }^{\mathrm{T}}$ was obtained by sequencing the PCR product obtained using primers Fd1 and S17, according to Berge et al. (2002). This new sequence was used for a BLAST search at NCBI and EBI and on a local database (not shown) containing 16S rRNA gene sequences of cultured species only to retrieve the most similar sequences. Among them, the sequence of Arthrobacter viscosus LMG $16473^{\mathrm{T}}$ (GenBank accession no. AJ639832) was found to be closely related to that of GBV016 ${ }^{\mathrm{T}}$. Arthrobacter viscosus is known to be an atypical Arthrobacter species (Keddie et al., 1986; Heyrman et al., 2005), and its position is uncertain. Moreover, only one 16S rRNA gene sequence of this species is available in GenBank. An eventual close relationship with Rhizobium must be investigated in detail, based on authentic strains, in order to allow a final taxonomic conclusion. A taxonomic transfer of this species would therefore be premature and it was removed from our phylogenetic study, as well as every sequence that was not described using a genus name (i.e. Rhizobium sp., etc.), providing a dataset of 97 sequences. All retrieved sequences were aligned and the alignment was checked visually and improved if necessary using SeaView (Galtier et al., 1996). A phylogenetic analysis was done using the neighbourjoining (BIONJ) method, which allowed clear positioning of strain $\mathrm{GBV} 016^{\mathrm{T}}$ within the Rhizobium cluster.

From the tree, only $16 \mathrm{~S}$ rRNA gene sequences for the most closely related type strains, along with those of strains YAS34 and USDA 1920, were retained, providing a dataset of 30 sequences. Alignments were checked again, and phylogenetic analyses were obtained using BIONJ (Kimura's two-parameter correction), DNAML (G option) and DNAPARS from the PHYLIP package. Positions 45-939 of the sequence of strain GBV016 ${ }^{\mathrm{T}}$ were used for these analyses. A strict consensus tree was derived (Fig. 1). Finally, a bootstrap analysis (1000 replications) was obtained using BIONJ as described above.

Phylogenetic analyses of $16 \mathrm{~S}$ rRNA gene sequences (Fig. 1) confirmed that strains GBV016 ${ }^{\mathrm{T}}$, YAS34 and USDA 1920 form a novel, robust branch in the Rhizobium phylogenetic tree, identified by all methods and $93 \%$ of bootstrap replications. Rhizobium sullae IS $123^{\mathrm{T}}$ is the closest type strain and, together, they form a separate clade. Apart from R. sullae $\mathrm{IS} 123^{\mathrm{T}}$, the closest type strains were Rhizobium indigoferae CCBAU $71042^{\mathrm{T}}$, R. yanglingense $\mathrm{SH} 22623^{\mathrm{T}}, R$. gallicum R602sp ${ }^{\mathrm{T}}$ and $R$. mongolense USDA $1844^{\mathrm{T}}$, and the latter strain was chosen together with $R$. sullae USDA $4950^{\mathrm{T}}$ $\left(=\mathrm{IS} 123^{\mathrm{T}}\right)$ to be tested in DNA-DNA hybridizations in order to delineate the novel Rhizobium species. Actual $16 \mathrm{~S}$ rRNA gene sequence similarities between GBV016 ${ }^{\mathrm{T}}$ and the type strains of these closely related species were $98.9 \%(R$. sullae $\mathrm{IS}_{123^{\mathrm{T}}}$ ) and $98.5 \%\left(R\right.$. mongolense USDA $\left.1844^{\mathrm{T}}\right)$.

DNA-DNA hybridization experiments were carried out in microtitre plates by using biotinylated probe DNA, as described by Ezaki et al. (1989) and improved by Willems et al. (2001). Hybridization was performed with denatured, sonicated, counterpart DNA labelled with photobiotin, for $3 \mathrm{~h}$ at $42{ }^{\circ} \mathrm{C}$ in $50 \%$ formamide. Cross-hybridization was done systematically and means were calculated (Supplementary Table S1). One main DNA hybridization group was clearly delineated, including the nine strains isolated from A. thaliana, as well as strains YAS34 and USDA 1920 (Supplementary Table S1). DNA-DNA

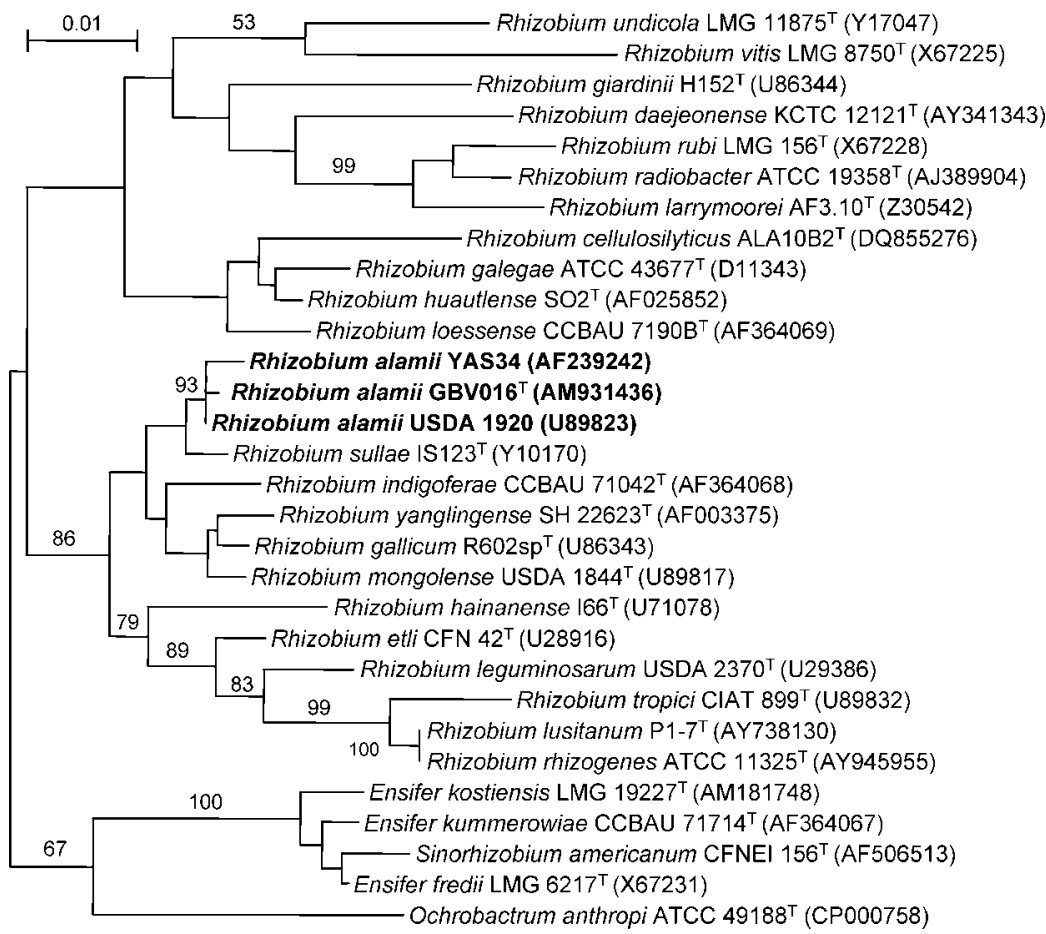

Fig. 1. Combined final dendrogram, displaying BIONJ topology based on nearly complete 16S rRNA gene sequences of strains GBV016 $^{\top}$, YAS34 and USDA 1920 and closely related type strains (see text). Bootstrap percentages (1000 replications) are shown only for branches that were also retrieved using the maximum-likelihood and parsimony analyses. Bar, 1 substitution per 100 nucleotide positions. 
hybridization values between these strains were higher than the recommended threshold value of $70 \%$ (except for the value of $66 \%$ relatedness obtained between strains GBV022 and GBV044), demonstrating that they belong to the same genomic species. DNA-DNA hybridization values between four strains of this group (including $\mathrm{GBV} 016^{\mathrm{T}}$ ) and the type strains $R$. sullae USDA $4950^{\mathrm{T}}$ and $R$. mongolense USDA $1844^{\mathrm{T}}$ were respectively $14-22 \%$ and $10-16 \%$, indicating a genetic distance that supports the conclusion that these strains constitute a novel species within the genus Rhizobium. This result is in agreement with those of van Berkum et al. (1998) showing that strain USDA 1920 does not belong to the species $R$. mongolense.

Phenotypic characterization of the strains from this study was based on metabolism of carbon sources, resistance to antibiotics and tolerance to salt. The strains were grown on $0.1 \times$ TSA for $24 \mathrm{~h}$ and characterized with Biolog GN2 and GP2 microplates. Antibiotic resistance and $\mathrm{NaCl}$ tolerance were assessed by growing the strains in microplates in

Table 2. Differential characteristics of Rhizobium alamii sp. nov. and type strains of related species

Strains: 1, R. alamii sp. nov. GBV016 ${ }^{\mathrm{T}}$ (numbers in parentheses indicate the number of the 11 strains that tested positive); 2 , $R$. sullae USDA $4950^{\mathrm{T}} ; 3, R$. mongolense USDA $1844^{\mathrm{T}} ; 4, R$. gallicum $\mathrm{R} 602 \mathrm{sp}^{\mathrm{T}}$. Unless indicated, data were obtained in this study. NA, No data available.

\begin{tabular}{|c|c|c|c|c|}
\hline Characteristic & 1 & 2 & 3 & 4 \\
\hline \multicolumn{5}{|c|}{ Utilization of carbon source in Biolog GN2 or GP2 microplate } \\
\hline D-Alanine (GN2) & $-(1)$ & + & + & + \\
\hline L-Leucine (GN2) & $-(2)$ & + & + & + \\
\hline L-Phenylalanine (GN2) & $-(0)$ & - & + & - \\
\hline Maltose (GN2/GP2) & $+(8)$ & - & + & - \\
\hline DL-Carnitine (GN2) & $+(8)$ & - & - & - \\
\hline$\alpha$-Ketobutyric acid (GN2) & $-(0)$ & + & + & + \\
\hline Glucuronamide (GN2) & $-(1)$ & + & + & + \\
\hline$\alpha$-Ketovaleric acid (GN2/GP2) & $-(0)$ & + & + & + \\
\hline Succinamic acid (GN2/GP2) & $-(1)$ & + & + & + \\
\hline L-Ornithine (GN2) & $-(0)$ & + & + & - \\
\hline$\gamma$-Hydroxybutyric acid (GN2/GP2) & $-(0)$ & + & + & - \\
\hline$\alpha$-Ketoglutaric acid (GN2/GP2) & $-(0)$ & + & + & - \\
\hline Putrescine (GP2) & $-(1)$ & - & + & + \\
\hline L-Pyroglutamic acid (GN2) & $-(1)$ & - & + & + \\
\hline Xylitol (GN2) & $+(10)$ & - & + & + \\
\hline D-Galactonic acid lactone (GN2) & $+(8)$ & - & + & + \\
\hline myo-Inositol (GP2) & $-(0)$ & - & + & - \\
\hline p-Hydroxyphenylacetic acid (GP2) & $-(1)$ & - & + & - \\
\hline$N$-Acetyl-L-glutamic acid (GP2) & $-(0)$ & - & + & - \\
\hline 2,3-Butanediol (GP2) & $-(1)$ & - & + & - \\
\hline 2,3-Butanediol (GN2) & $-(1)$ & - & - & + \\
\hline Glucose 1-phosphate (GP2) & $-(0)$ & - & + & - \\
\hline Glucose 6-phosphate (GP2) & $-(0)$ & - & + & - \\
\hline Formic acid (GN2) & $+(8)$ & + & + & - \\
\hline D-Ribose (GP2) & $+(11)$ & + & + & - \\
\hline Methyl pyruvate (GN2) & $-(1)$ & - & - & + \\
\hline \multicolumn{5}{|l|}{ Growth in: } \\
\hline $0.1 \% \mathrm{NaCl}$ & $-(0)$ & $+{ }^{a *}$ & - & NA \\
\hline $0.5 \% \mathrm{NaCl}$ & $-(0)$ & $+{ }^{a}$ & - & $+^{b}$ \\
\hline $1 \% \mathrm{NaCl}$ & $-(0)$ & $+{ }^{a}$ & - & $-{ }^{b}$ \\
\hline $2 \% \mathrm{NaCl}$ & $-(0)$ & $-{ }^{a}$ & - & $-{ }^{b}$ \\
\hline \multicolumn{5}{|l|}{ Antibiotic resistance } \\
\hline Streptomycin $\left(3 \mu \mathrm{g} \mathrm{ml}^{-1}\right)$ & $-(0) \dagger$ & NA & + & NA \\
\hline Kanamycin $\left(10 \mu \mathrm{g} \mathrm{ml}^{-1}\right)$ & $-(0) \dagger$ & $+{ }^{a}$ & NA & $+^{b}$ \\
\hline Nalidixic acid $\left(40 \mu \mathrm{g} \mathrm{ml}^{-1}\right)$ & $+(4) \dagger$ & $+{ }^{a}$ & NA & $+{ }^{b}$ \\
\hline
\end{tabular}

${ }^{\star}$ Data taken from: a, Amarger et al. (1997); b, Struffi et al. (1998).

$\dagger$ Only four strains were tested, including the type strain. 
tenfold-diluted tryptic soy broth $(0.1 \times \mathrm{TSB})$ containing the following: streptomycin $\left(3 \mu \mathrm{g} \mathrm{ml} \mathrm{ml}^{-1}\right)$, kanamycin $\left(10 \mu \mathrm{g} \mathrm{ml}^{-1}\right)$, nalidixic acid $\left(40 \mu \mathrm{g} \mathrm{ml}^{-1}\right)$ or $\mathrm{NaCl}(0.1$, $0.5,1$ and $2 \%)$.

Slight differences in Biolog metabolic fingerprints were observed between the 11 strains belonging to the novel species, but they showed several differences compared with their closest relatives $R$. sullae USDA $4950^{\mathrm{T}}, R$. mongolense USDA $1844^{\mathrm{T}}$ and $R$. gallicum R602sp ${ }^{\mathrm{T}}$ (Table 2). They all differ clearly from R. sullae USDA $4950^{\mathrm{T}}$ in metabolism of $\alpha$-ketobutyric acid, $\alpha$-ketovaleric acid, L-ornithine, $\gamma$ hydroxybutyric acid and $\alpha$-ketoglutaric acid, growth in $0.1,0.5$ and $1 \% \mathrm{NaCl}$ and kanamycin resistance. They differ from $R$. mongolense USDA $1844^{\mathrm{T}}$ in metabolism of $\mathrm{L}-$ phenylalanine, $\alpha$-ketobutyric acid, $\alpha$-ketovaleric acid, Lornithine, $\gamma$-hydroxybutyric acid, $\alpha$-ketoglutaric acid, myoinositol, $\mathrm{N}$-acetyl L-glutamic acid, glucose 1-phosphate and glucose 6-phosphate and streptomycin resistance. They differ from $R$. gallicum $\mathrm{R} 602 \mathrm{sp}^{\mathrm{T}}$ in metabolism of $\alpha$ ketobutyric acid, $\alpha$-ketovaleric acid and D-ribose and growth in $0.5 \% \mathrm{NaCl}$ (Table 2).

Nodulation was tested by van Berkum et al. (1998) only in a symbiotic context, by inoculating strain USDA 1920 to M. ruthenica and Medicago sativa (alfalfa). These authors showed that strain USDA1920 nodulates the two Medicago species; however, it was only capable of nitrogen fixation with $M$. ruthenica, since alfalfa plants were small and chlorotic.

In conclusion, our data based on a polyphasic taxonomic study demonstrate that the EPS-producing Rhizobium isolates analysed in the present study represent a novel species that can be differentiated genotypically and phenotypically from their nearest phylogenetic neighbours. We therefore propose the name Rhizobium alamii sp. nov. to accommodate these isolates. The examined isolates produced large amounts of EPS and, except USDA 1920, they were associated with non-legumes.

\section{Description of Rhizobium alamii sp. nov.}

Rhizobium alamii (a.la'mi.i. N.L. gen. masc. n. alamii of Alami, named in honour of Younes Alami, who isolated strain YAS34 and demonstrated its effect on non-legume plant growth).

Gram-negative rods, $0.7 \times 1.0 \mu \mathrm{m}$, motile, aerobic, catalase-positive and oxidase-negative. Colonies are white, circular or irregular, raised and mucous, $3-4 \mathrm{~mm}$ in diameter within 3 days on $0.1 \times$ TSA at $30{ }^{\circ} \mathrm{C}$. Cells grow in $0.1 \times$ TSB or tenfold-diluted Luria-Bertani (LB) broth, but not in undiluted TSB or LB broth. No growth is observed at $\mathrm{NaCl}$ concentrations of $0.1 \%$ or above. Grows on glucose, sucrose or mannitol, leading to the production of large amounts of EPS slime. No growth with fructose or succinate as carbon and energy sources. Carbon sources used are reported in Table 2. All known strains use Lfucose, lactulose, D-xylose and D-malic acid but not itaconic acid, L-ornithine, L-phenylalanine, D-serine, $\gamma$ aminobutyric acid, thymidine, phenylethylamine, methyl $\alpha$-D-glucoside, lactamide, L-alaninamide, $2^{\prime}$-deoxyadenosine or DL- $\alpha$-glycerol phosphate. Strains are resistant to nalidixic acid $\left(40 \mu \mathrm{g} \mathrm{ml}^{-1}\right)$ but susceptible to streptomycin $\left(3 \mu \mathrm{g} \mathrm{ml}^{-1}\right)$ and kanamycin $\left(10 \mu \mathrm{g} \mathrm{ml}^{-1}\right)$. The strains can be distinguished by their 16S rRNA gene sequence and by DNA hybridization.

The type strain, GBV016 ${ }^{\mathrm{T}}\left(=\mathrm{CFBP} 7146^{\mathrm{T}}=\mathrm{LMG} 24466^{\mathrm{T}}\right)$, was isolated from rhizosphere soil of Arabidopsis thaliana. Strains YAS34, USDA 1920, GBV022, GBV023, GBV024, GBV037, GBV044, GBV081, ALV118 and ALV104, also assigned to the species, were isolated from the rhizosphere and roots of $A$. thaliana plantlets, from sunflower roots or from Medicago ruthenica nodules.

\section{Acknowledgements}

We thank G. Laguerre (INRA, Dijon, France) for providing $R$. gallicum R602sp ${ }^{\mathrm{T}}$, P. van Berkum and P. Elia (USDA Rhizobium Germplasm Resource Center, Beltsville, MD, USA) for providing Rhizobium sp. USDA 1920, R. mongolense USDA $1844^{\mathrm{T}}$ and $R$. sullae USDA $4950^{\mathrm{T}}$, J. Euzéby for his help in correct naming of the species and P. De Vos for his expertise on the taxonomic position of $A$. viscosus. We are grateful to J. Maurel, J. Thomas, S. Fochesato and A. Hertz for their helpful assistance. Plants were grown in our institute with the help of the platform GRAP, IBEB/SBVME, Cadarache, France.

\section{References}

Achouak, W., Conrod, S., Cohen, V. \& Heulin, T. (2004). Phenotypic variation of Pseudomonas brassicacearum as a plant root-colonization strategy. Mol Plant Microbe Interact 17, 872-879.

Alami, Y., Heulin, T., Milas, M., de Baynast, R., Heyraud, A. \& Villain, A. (1998). Polysaccharide microorganism and method for obtaining same composition containing it and application. European patent no. 97-1624970212.

Alami, Y., Achouak, W., Marol, C. \& Heulin, T. (2000). Rhizosphere soil aggregation and plant growth-promotion of sunflowers by an exopolysaccharide-producing Rhizobium sp. strain isolated from sunflower roots. Appl Environ Microbiol 66, 3393-3398.

Altschul, S. F., Madden, T. L., Schäffer, A. A., Zhang, J., Zhang, Z., Miller, W. \& Lipman, D. J. (1997). Gapped BLAST and PSI-BLAST: a new generation of protein database search programs. Nucleic Acids Res 25, 3389-3402.

Amarger, N., Macheret, V. \& Laguerre, G. (1997). Rhizobium gallicum sp. nov. and Rhizobium giardinii sp. nov., from Phaseolus vulgaris nodules. Int J Syst Bacteriol 47, 996-1006.

Amellal, N., Burtin, G., Bartoli, F. \& Heulin, T. (1998). Colonization of wheat roots by an exopolysaccharide-producing Pantoea agglomerans strain and its effect on rhizosphere soil aggregation. Appl Environ Microbiol 64, 3740-3747.

Berge, O., Guinebretière, M. H., Achouak, W., Normand, P. \& Heulin, T. (2002). Paenibacillus graminis sp. nov. and Paenibacillus odorifer sp. nov., isolated from plant roots, soil and food. Int J Syst Evol Microbiol 52, 607-616.

Denison, R. F. \& Kiers, E. T. (2004). Lifestyle alternatives for rhizobia: mutualism, parasitism, and forgoing symbiosis. FEMS Microbiol Lett 237, 187-193. 
Derrien, D., Marol, C., Balabane, M. \& Balesdent, J. (2006). The turnover of carbohydrate carbon in a cultivated soil estimated by ${ }^{13} \mathrm{C}$ natural abundance. Eur J Soil Sci 57, 547-557.

Ezaki, T., Hashimoto, Y. \& Yabuuchi, E. (1989). Fluorometric deoxyribonucleic acid-deoxyribonucleic acid hybridization in microdilution wells as an alternative to membrane filter hybridization in which radioisotopes are used to determine genetic relatedness among bacterial strains. Int J Syst Bacteriol 39, 224-229.

Frey, P., Frey-Klett, P., Garbaye, J., Berge, O. \& Heulin, T. (1997). Metabolic and genotypic fingerprinting of fluorescent pseudomonads associated with the Douglas fir-Laccaria bicolor mycorrhizosphere. Appl Environ Microbiol 63, 1852-1860.

Galtier, N., Gouy, M. \& Gautier, C. (1996). SeaView and PHYLO_WIN, two graphic tools for sequence alignment and molecular phylogeny. Comput Appl Biosci 12, 543-548.

Garcia-Fraile, P., Rivas, P., Willems, A., Peix, A., Martens, M., Martinez-Molina, E., Mateos, P. F. \& Velazquez, E. (2007). Rhizobium cellulosilyticum sp. nov., isolated from sawdust of Populus alba. Int J Syst Evol Microbiol 57, 844-848.

Heyrman, J., Verbeeren, J., Schumann, P., Swings, J. \& De Vos, P. (2005). Six novel Arthrobacter species isolated from deteriorated mural paintings. Int J Syst Evol Microbiol 55, 1457-1464.

Hunter, W. J., Kuykendall, L. D. \& Manter, D. K. (2007). Rhizobium selenireducens sp. nov.: a selenite-reducing alpha-proteobacteria isolated from a bioreactor. Curr Microbiol 55, 455-460.

Keddie, R. M., Collins, M. D. \& Jones, D. (1986). Genus Arthrobacter Conn and Dimmick 1947, 300 ${ }^{\mathrm{AL}}$. In Bergey's Manual of Systematic Bacteriology, vol. 2, pp. 1288-1301. Edited by P. H. A. Sneath, N. S. Mair, M. E. Sharpe \& J. G. Holt. Baltimore: Williams \& Wilkins.

Laguerre, G., Bardin, M. \& Amarger, N. (1993). Isolation from soil of symbiotic and non-symbiotic Rhizobium leguminosarum by DNA hybridization. Can J Microbiol 39, 1142-1149.

Lindström, K. \& Martinez-Romero, E. (2007). International Committee on Systematics of Prokaryotes Subcommittee on the taxonomy of Agrobacterium and Rhizobium. Minutes of the meeting, 23-24 July 2006, Århus, Denmark. Int J Syst Evol Microbiol 57, 13651366.

Lodhi-Hassan, A., Heulin, T., Milas, M., Heyraud, A., Achouak, W. Berge, O., Deline, L., Sanhaji, G., Bresin, A. (2006). Nouveau polysaccharide, son procédé de préparation et ses utilisations notamment dans le domaine cosmétique. French patent no. 06/08840, 9 October 2006.

Quan, Z.-X., Bae, H.-S., Baek, J.-H., Chen, W.-F., Im, W.-T. \& Lee, S.-T. (2005). Rhizobium daejeonense sp. nov. isolated from a cyanide treatment bioreactor. Int J Syst Evol Microbiol 55, 2543-2549.
Quigley, P. E., Cunningham, P. J., Hannah, M., Ward, G. N. \& Morgan, T. (1997). Symbiotic effectiveness of Rhizobium leguminosarum bv. trifolii collected from pastures in south western Victoria. Aust J Exp Agric 37, 623-630.

Rosenblueth, M. \& Martinez-Romero, E. (2004). Rhizobium etli maize populations and their competitiveness for root colonization. Arch Microbiol 181, 337-344.

Segovia, L., Pinero, D., Palacios, R. \& Martinez-Romero, E. (1991). Genetic structure of a soil population of nonsymbiotic Rhizobium leguminosarum. Appl Environ Microbiol 57, 426-433.

Soberon-Chavez, G. \& Najera, R. (1988). Isolation from soil of Rhizobium leguminosarum lacking symbiotic information. Can $J$ Microbiol 35, 464-468.

Squartini, A., Struffi, P., Döring, H., Selenska-Pobell, S., Tola, E., Giacomini, A., Vendramin, E., Velazquez, E., Mateos, P. F. \& other authors (2002). Rhizobium sullae sp. nov. (formerly 'Rhizobium hedysari'), the root-nodule microsymbiont of Hedysarum coronarium L. Int J Syst Evol Microbiol 52, 1267-1276.

Struffi, P., Corich, V., Giacomini, A., Benguedouar, A., Squartini, A., Casella, S. \& Nuti, M. P. (1998). Metabolic properties, stress tolerance and macromolecular profiles of rhizobia nodulating Hedysarum coronarium. J Appl Microbiol 84, 81-89.

Sullivan, J. T., Eardly, B. D., van Berkum, P. \& Ronson, C. W. (1996). Four unnamed species of nonsymbiotic rhizobia isolated from the rhizosphere of Lotus corniculatus. Appl Environ Microbiol 62, 28182825.

van Berkum, P., Beyene, D., Bao, G., Campbell, T. A. \& Eardly, B. D. (1998). Rhizobium mongolense sp. nov. is one of three rhizobial genotypes identified which nodulate and form nitrogen-fixing symbioses with Medicago ruthenica [(L.) Ledebour]. Int J Syst Bacteriol 48, 13-22.

Willems, A., Doignon-Bourcier, F., Goris, J., Coopman, R., de Lajudie, P., De Vos, P. \& Gillis, M. (2001). DNA-DNA hybridization study of Bradyrhizobium strains. Int J Syst Evol Microbiol 51, 13151322.

Yanni, Y. G., Rizk, R. Y., Corich, V., Squartini, A., Ninke, K., PhilipHollingsworth, S., Orgambide, G., de Bruijn, F., Stoltzfus, J. \& other authors (1997). Natural endophytic association between Rhizobium leguminosarum bv. trifolii and rice roots and assessment of its potential to promote rice growth. Plant Soil 194, 99-114.

Young, J. M., Kuykendall, L. D., Martínez-Romero, E., Kerr, A. \& Sawada, H. (2001). A revision of Rhizobium Frank 1889, with an emended description of the genus, and the inclusion of all species of Agrobacterium Conn 1942 and Allorhizobium undicola de Lajudie et al. 1998 as new combinations: Rhizobium radiobacter, $R$. rhizogenes, $R$. rubi, R. undicola and R. vitis. Int J Syst Evol Microbiol 51, 89-103. 